\title{
Calycosin suppresses TGF- $\beta$-induced epithelial-to-mesenchymal transition and migration by upregulating BATF2 to target PAI-1 via the Wnt and PI3K/Akt signaling pathways in colorectal cancer cells
}

Qun Wang ${ }^{1,2,3,4^{*}+}$, Weijun Lu ${ }^{1,2}$, Tao Yin ${ }^{1,2}$ and Li Lu $\mathrm{Lu}^{2,3,4,5^{*}+}$

\begin{abstract}
Objectives: To determine whether the upregulation of basic leucine zipper ATF-like transcription factor 2 (BATF2) by calycosin suppresses the growth and epithelial-to-mesenchymal transition (EMT) in human colorectal cancer (CRC) cells.

Method: Cells were cultured and treated with different concentrations of calycosin for different periods of time. Protein and mRNA expression was determined by western blotting and quantitative PCR. Cell migration was assessed by Transwell experiments. Co-immunoprecipitation and luciferase assays were used to analyze the association between BATF2 and plasminogen activator inhibitor-1.

(PAI-1). Cell apoptosis was determined by flow cytometry; $\beta$-catenin cellular localization was visualized by immunofluorescent staining.

Results: Calycosin up-regulated the expression of BATF2 via the signal transducer and activator of transcription 3 (STAT3) pathway, which was antagonized by transforming growth factor beta (TGF- $\beta$ ), calycosin promoted the cell apoptosis and growth inhibition via phosphoinositide 3-kinase (PI3K)/Akt pathway. TGF- $\beta$ promoted cell growth, which was inhibited by calycosin regulating the expression of proliferating cell nuclear antigen (PCNA) via the phosphoinositide 3-kinase pathway. TGF- $\beta$ suppressed expression of BAX via the phosphoinositide 3-kinase pathway but induced cell apoptosis .calycosin enhanced the effect of TGF- $\beta$ on cell apoptosis, In addition, calycosin suppressed TGF- $\beta$-induced cell migration by increasing BATF2 to target PAl-1. TGF- $\beta$-induced EMT was inhibited by calycosin in human CRC LoVo and HCT116 cell lines via the Wnt signaling pathway.
\end{abstract}

Conclusions: The induction of BATF2 by calycosin may be a feasible therapeutic option for CRC.

Keywords: BATF2, Calycosin, Cell migration, Colorectal cancer, PAI-1

\footnotetext{
*Correspondence: swander@126.com; luli117@163.com

${ }^{\dagger}$ Qun Wang and Li Lu contributed equally to this work

'Department of Hepatopancreatobiliary Surgery, Hubei Cancer Hospital, Wuhan, Hubei 430079, People's Republic of China

${ }^{2}$ Department of Medical Oncology, Hubei Cancer Hospital, Tongji Medical

College, Huazhong University of Science and Technology, Wuhan, Hubei

430079, People's Republic of China

Full list of author information is available at the end of the article
}

C The Author(s). 2019 Open Access This article is distributed under the terms of the Creative Commons Attribution 4.0 International License (http://creativecommons.org/licenses/by/4.0/), which permits unrestricted use, distribution, and reproduction in any medium, provided you give appropriate credit to the original author(s) and the source, provide a link to the Creative Commons license, and indicate if changes were made. The Creative Commons Public Domain Dedication waiver (http://creativecommons.org/publicdomain/zero/1.0/) applies to the data made available in this article, unless otherwise stated. 


\section{Background}

The basic leucine zipper (bZIP) ATF-like transcription factor (BATF) family [1] is a subgroup of the larger family of bZIP transcription factors, and its members belong to the AP-1 family of transcription factors. Functional analyses of BATF in cell culture systems and transgenic mice have demonstrated that it was a negative regulator of AP-1-mediated gene expression $[2,3]$, and cellular transformation by oncogenes that rely on robust AP-1 activity was blocked by the coexpression of BATF [2]. Recently, the induction of BATF2 was found to inhibit the hepatocyte growth factor (HGF)/MET signaling pathway [4] and to suppress angiogenesis and tumor growth by directly targeting ceruloplasmin via inhibition of the activity of the hypoxia inducible factor 1 alpha (HIF-1 $\alpha$ )/vascular endothelial growth factor (VEGF) axis in colorectal cancer (CRC) cells [5].BATF2 regulates numerous cellular processes including growth inhibition and promotion of apoptosis [6, 7]. However, it's role in the epithelial-to-mesenchymal transition (EMT) of CRC cells is unclear TGF- $\beta$ signaling and activated Ras pathways have been implicated as key EMT inducers in CRC [8, 9], as localized CRC cells respond to TGF- $\beta$ with growth inhibition and metastatic carcinoma cells proliferate after treatment with TGF- $\beta$ $[10-12]$. Increased TGF- $\beta$ levels within a primary tumor and high plasma levels of TGF- $\beta$ correlate with a poor prognosis in patients with CRC $[10,11]$. Wnt, phosphoinositide 3-kinase (PI3K)/Akt, and other signaling pathways may also play important roles in the EMT process during the progression of CRC [13-16]. Signal transducer and activator of transcription 3 (STAT3) is another important signaling pathway in the regulation of EMT in CRC. STAT3 interacts directly with Smad3 in vivo and in vitro, resulting in the attenuation of Smad3-Smad4 complex formation and suppression of Smad3 DNA binding to block TGF- $\beta$ signaling [17]. BATF is a direct target of STAT3 [18]; thus, we were interested in determining the role of BATF2 in the STAT3-mediated inhibition of TGF- $\beta$-induced EMT in CRC.

We used the active components of the traditional Chinese medicine flavonoid calycosin $\left(\mathrm{C}_{16} \mathrm{H}_{12} \mathrm{O}_{5}\right)$ to upregulate BATF2 expression, and analyzed it's effects on cell growth, apoptosis, migration, and EMT in CRC. The results showed that calycosin up-regulated BATF2 expression. This effect was inhibited by TGF- $\beta$ via the STAT3 signaling pathway, which resulted in the inhibition of cell growth and the promotion of apoptosis through the PI3K pathway by Akt phosphorylation. Calycosin blocked TGF- $\beta$-induced migration and EMT by altering the expression of plasminogen activator inhibitor-1 (PAI-1) via the Wnt signaling pathway in
LoVo and HCT116 human CRC cells. The results of this study suggested that the up-regulation of BATF2 by calycosin may be a therapeutic option for CRC.

\section{Materials and methods Cell culture}

HCT116 and LoVo human CRC cell lines were obtained from Wuhan HealthCare Biotechnology Company (Wuhan, China). Cells were maintained in RPMI 1640 medium with $10 \%$ fetal bovine serum and incubated at $37^{\circ} \mathrm{C}$ with $5 \% \mathrm{CO}_{2}$ in a humidified atmosphere. Lipofectamine ${ }^{\circ}$ RNAiMAX (Invitrogen, Carlsbad, CA), First Strand cDNA Synthesis Kit (TaKaRa, Dalian, China), and LY294002 (Promega, Fitchburg, WI) were used on the cells.

\section{MTT cell viability assay}

The anti-proliferation effects of calycosin against tumor cells were evaluated by an MTT cell viability assay. Briefly, the cells were cultured in 96-well plates $(5.0 \times$ $10^{3}$ cells/well) for $12 \mathrm{~h}$, and then incubated with various concentrations of calycosin $(0,50,100,150 \mu \mathrm{M}$, Phytomarker Ltd., Tianjin, China). After 6, 12, 24, and $48 \mathrm{~h}$, cell viability was analyzed. The cells were treated with phosphate-buffered saline (PBS), LY294002, or LY294002 with TGF- $\beta$ or calycosin. Optical density was read at $490 \mathrm{~nm}$ using a microplate reader (Bio-Tek Instruments, Winooski, VT). Cells were counted and a growth curve was generated.

\section{Quantitative PCR}

Total RNA was extracted using the TRIzol reagent (Invitrogen), and first-strand cDNA was synthesized using M-MLV reverse transcriptase (TaKaRa). Quantitative PCR was performed in triplicate with SYBRII qPCR Master Mix according to the manufacturer's protocol, using glyceraldehyde-3-phosphate dehydrogenase (GAPDH) as a control. The relative mRNA levels of the target genes were calculated with the $2^{-\Delta \Delta \mathrm{Ct}}$ method.

\section{Western blot analysis}

Total proteins were extracted from the cells and the concentrations were determined using a Bradford Protein Assay Kit (Beyotime Biotechnology, Beijing, China). The proteins $(70 \mu \mathrm{g} / \mathrm{lane})$ were separated on $10 \%$ sodium dodecyl sulfate-polyacrylamide gels and transferred to polyvinylidene difluoride membranes (Pierce, Waltham, MA). After blocking in 5\% fat-free dry milk in Tris-buffered saline containing $0.1 \%$ Tween for $2 \mathrm{~h}$, the membranes were incubated separately overnight at $4{ }^{\circ} \mathrm{C}$ with 1:1000 dilutions of primary antibodies against BATF2, PAI-1, GAPDH, phosphorylated (p)-STAT3, BCL2-associated X (BAX), Akt, p-Akt, STAT3, and proliferating cell nuclear antigen (PCNA) (all from 
bioswamp Biotechnology, China). After washing, the membranes were incubated separately with corresponding horseradish peroxidase-conjugated secondary antibodies (Zhongshan Biotechnology, Beijing, China) for 1 $h$ at room temperature. Subsequently, the membranes were washed and the signals were visualized with SuperSignal West Dura Extended Duration Substrate.

\section{Cell migration assay}

For migration assays, $3.0 \times 10^{4}$ cells were seeded into the upper chamber of an $8-\mu \mathrm{M}$ pore Transwell in $100 \mu \mathrm{L}$ Dulbecco's modified Eagle's medium containing $0.2 \%$ bovine serum albumin. Cells were allowed to migrate for 5 $\mathrm{h}$ through the medium, $12 \mathrm{~h}$ through collagen, and $21 \mathrm{~h}$ through Matrigel. The migrated cells were fixed, stained, and counted in six random fields and averaged. The experiments were repeated three times.

\section{Co-immunoprecipitation assay}

For the co-immunoprecipitation assay, LoVo cells were divided into two groups. Cell lysates were made from one group for subsequent western blot analysis. The remaining group was cultured with PBS (control), $100 \mu \mathrm{M}$ calycosin, or $20 \mathrm{ng} / \mathrm{mL}$ TGF- $\beta$ and $100 \mu \mathrm{M}$ calycosin for $48 \mathrm{~h}$, after which the cells were lysed. After prewashing with lysis buffer, $10 \mu \mathrm{L}$ Protein A agarose beads was incubated with anti-BATF2 or IgG antibodies at room temperature for $10 \mathrm{~min}$. The beads were mixed with the cell lysate overnight at $4{ }^{\circ} \mathrm{C}$. The complex was eluted using an elution buffer (glycine $\mathrm{HCl}, \mathrm{pH} 3.0$ ), followed by heating for $10 \mathrm{~min}$ at $70{ }^{\circ} \mathrm{C}$.

\section{Plasmid construction}

The DNA fragment encoding the BATF2 gene was amplified from human cDNA with the following primers: BATF2 forward CTAGCTAGCGATGGATTGTGCCTC; and reverse CGGAATTCTGTTAGAAGTGGACTTG; the bold font indicates where the HindIII and XhoI cloning sites were introduced. The cDNA fragment obtained was verified by sequencing and cloned into pEGFP-N1 between the HindIII and XhoI sites to obtain pEGFPN1-BATF2. The wild-type (WT) DNA fragment containing part of the promoter region ( -627 to -636 from the transcription initiation site) of the PAI-1 gene was amplified from human genomic DNA with the following primers: forward GTAGCTAGCTAGCACAGAGAGAGTCTGGACAC; and reverse CCCTCGAGGGGCAGTCACCCCTAGGGCA. The DNA fragment obtained was cloned directly into the pGL3-Basic vector (Promega) between the KpnI and BglII sites to obtain pGL3-PAI-1-WT. A mutant (MT) DNA sequence of the PAI-1 promoter region encompassing one putative BATF2 binding site ( -627 to -636 from the transcription initiation site) was synthesized and inserted into the
pGL3-Basic vector. The MT construct was designated pGL3-PAI-1-MT. Three small interfering RNAs (siRNAs) targeting PAI-1 (siPAI-1) were synthesized and constructed by Wuhan HealthCare Biotechnology Company (Wuhan, China). siPAI-1-3, with a silencing target sequence of 5' -GCTGACTTCACGAGTCTTT-3', was the most transfection-efficient and was chosen for additional study. All plasmid constructs were confirmed by PCR.

\section{Luciferase reporter assays}

Cells were grown at a density of $1.0 \times 10^{5}$ cells/well in 6well culture plates and transfected with plasmid DNA using Lipofectamine 2000 (Invitrogen) for $24 \mathrm{~h}$. For luciferase assays, the cells were transiently co-transfected with the reporter gene construct (pEGFP-N1-BATF2), pGL3-PAI-1-MT, pGL3-PAI-1-WT, and pGL3-Basic plasmid encoding Renilla luciferase. The cells were incubated for $24 \mathrm{~h}$ and then mixed with PBS (control), $100 \mu \mathrm{M}$ calycosin, $20 \mathrm{ng} / \mathrm{mL}$ TGF- $\beta$, or calycosin with TGF- $\beta$ for 48 h. Firefly and Renilla luciferase activity was determined using the dual-luciferase reporter assay system (Promega).

\section{Flow cytometry}

The cells were collected, washed with cold PBS, and suspended in $500 \mu \mathrm{l}$ binding buffer. Then $5 \mu \mathrm{l}$ Annexin VFITC and $5 \mu \mathrm{l}$ propidium iodide (Keygen, Nanjing, China) were added and mixed with the cells. After the incubation at room temperature for $15 \mathrm{~min}$ in the dark, the cells were subjected to flow cytometry analysis. The percentage of apoptotic cells was calculated as the sum of cells stained with both Annexin V and PI versus the cells stained only with Annexin V.

\section{Cytoimmunofluorescence staining}

Different treated HCT116 and LoVo cells were seeded into 48-well plates for routine culturing. After washing in PBS, cells were fixed in $4 \%$ formaldehyde for $20 \mathrm{~min}$ at room temperature, treated with $0.5 \%$ Triton, and then blocked in $5 \%$ bovine serum albumin (BSA) at room temperature for $1 \mathrm{~h}$. The cells were then incubated with goat anti-human $\beta$-catenin antibody (1100, bioswamp China) at at room temperature for $1 \mathrm{~h}$ and Anti-Rabbit IgG (1200, bioswamp) at $37^{\circ} \mathrm{C}$ temperature in the dark for $1 \mathrm{~h}$. After nuclear staining with $5 \mu \mathrm{g} / \mathrm{ml}$ DAPI for 1 min, cells were observed under an inverted microscope (DMIL LED). Negative control was performed by replacing the primary antibody with PBS.

\section{Statistical analysis}

The results are expressed as the means \pm standard deviations. Comparisons between multiple groups were made using a one-way analysis of variance (ANOVA), followed 
by Tukey's post hoc test. Statistical analyses were conducted with The SPSS19.0 (SPSS Inc., Chicago, IL, USA) . Significance was defined as $p<0.05$.

\section{Results}

Calycosin inhibits growth in dose- and time-dependent manners

As shown in Fig. 1a, calycosin inhibited the proliferation of LoVo cells in dose- and time dependent manners (Fig. 1a). This inhibition was significant at concentrations of 50 and $100 \mu \mathrm{M}$ at $48 \mathrm{~h}$ or at a concentration of $150 \mu \mathrm{M}$ at 12 or $48 \mathrm{~h}$ compared to control cells $(P<0.05)$. BATF2 overexpression was induced by treatment with $100 \mu \mathrm{M}$ calycosin for $48 \mathrm{~h}(P<0.01)$. Cell migration was inhibited significantly at $100 \mu \mathrm{M} 48 \mathrm{~h}$ (Fig. 2a and b). On the basis of these results, we treated the cells with $100 \mu \mathrm{M}$ calycosin (Fig. 1b) for 6,12 , and $48 \mathrm{~h}$. LoVo cell growth in the treatment group was suppressed with $100 \mu \mathrm{M}$ calycosin at 12,24 , and
$48 \mathrm{~h}$ compared to the control group $(P<0.05)$. Thus, in the following experiments, the cells were treated with $100 \mu \mathrm{M}$ calycosin for $48 \mathrm{~h}$.

\section{Calycosin up-regulates BATF2 expression, which is} inhibited by TGF- $\beta$ via the STAT3 signaling pathway to promote growth inhibition involving Akt phosphorylation To investigate the effects of calycosin- and TGF- $\beta$-induced BATF2 expression on cell growth and apoptosis, BATF2, STAT3, p-STAT3, BAX (marker of apoptosis), PCNA (marker of proliferation), and p-Akt levels were evaluated by western blotting. The expression of p-STAT3, which has binding sites in the BATF2 promoter [18], was increased by TGF- $\beta$ and decreased by calycosin $(P<0.05)$. There was no significant difference in STAT3 expression (Fig. 3a). Cell growth was regulated by the PI3K signaling pathway activated by $\mathrm{p}$-Akt, which was increased by TGF- $\beta$ and decreased by calycosin $(P<0.05)$ (Fig. 3a). When calycosin
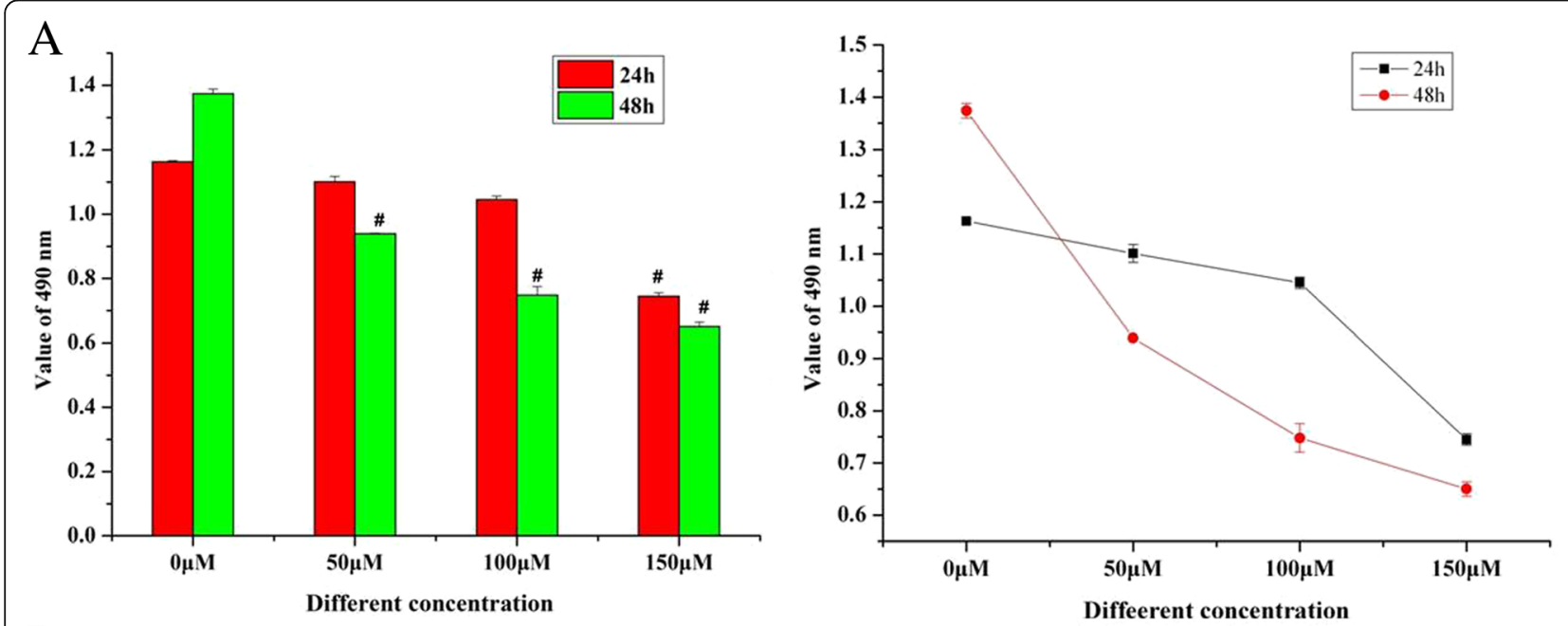

B
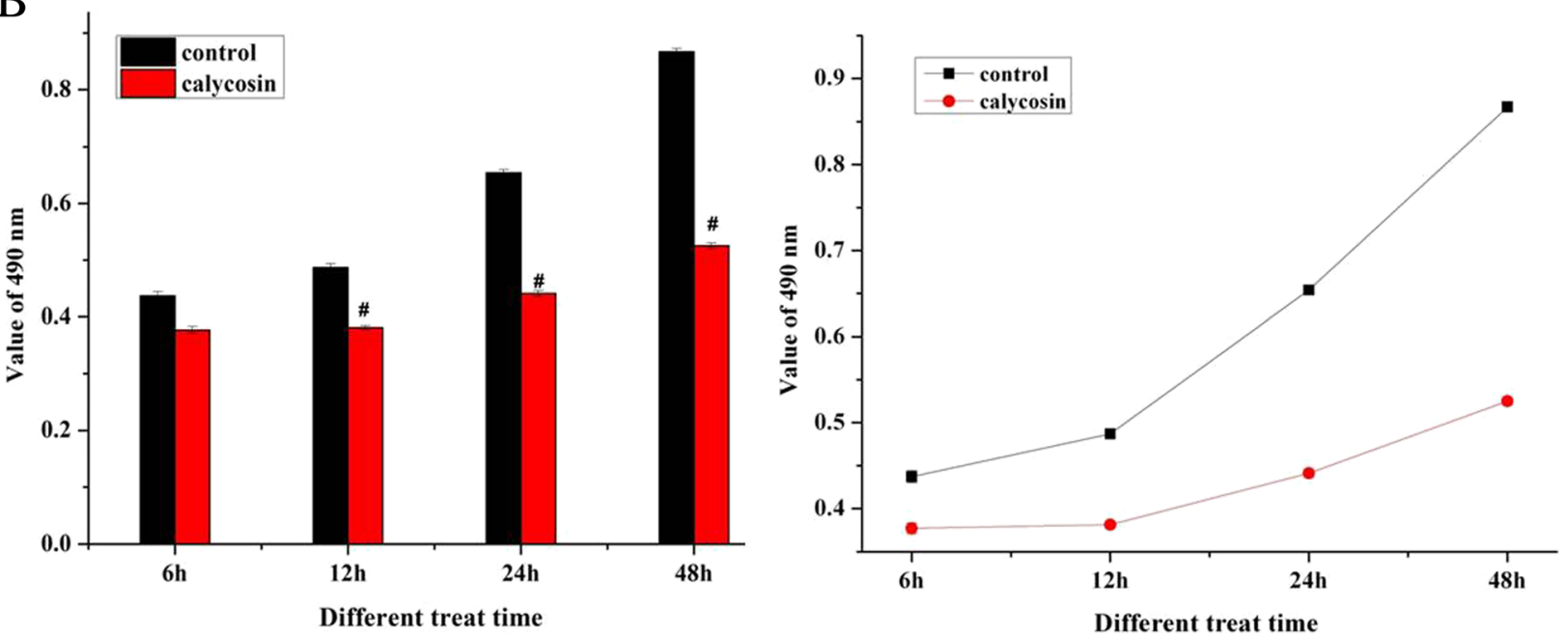

Fig. 1 a Growth inhibition of CRC LoVo cells was significantly promoted by calycosin in a dose- and time-dependent manner. $\mathbf{b}$ Proliferation of LoVo cells was inhibited by treatment with $100 \mu \mathrm{M}$ calycosin for $12 \mathrm{~h}$ 


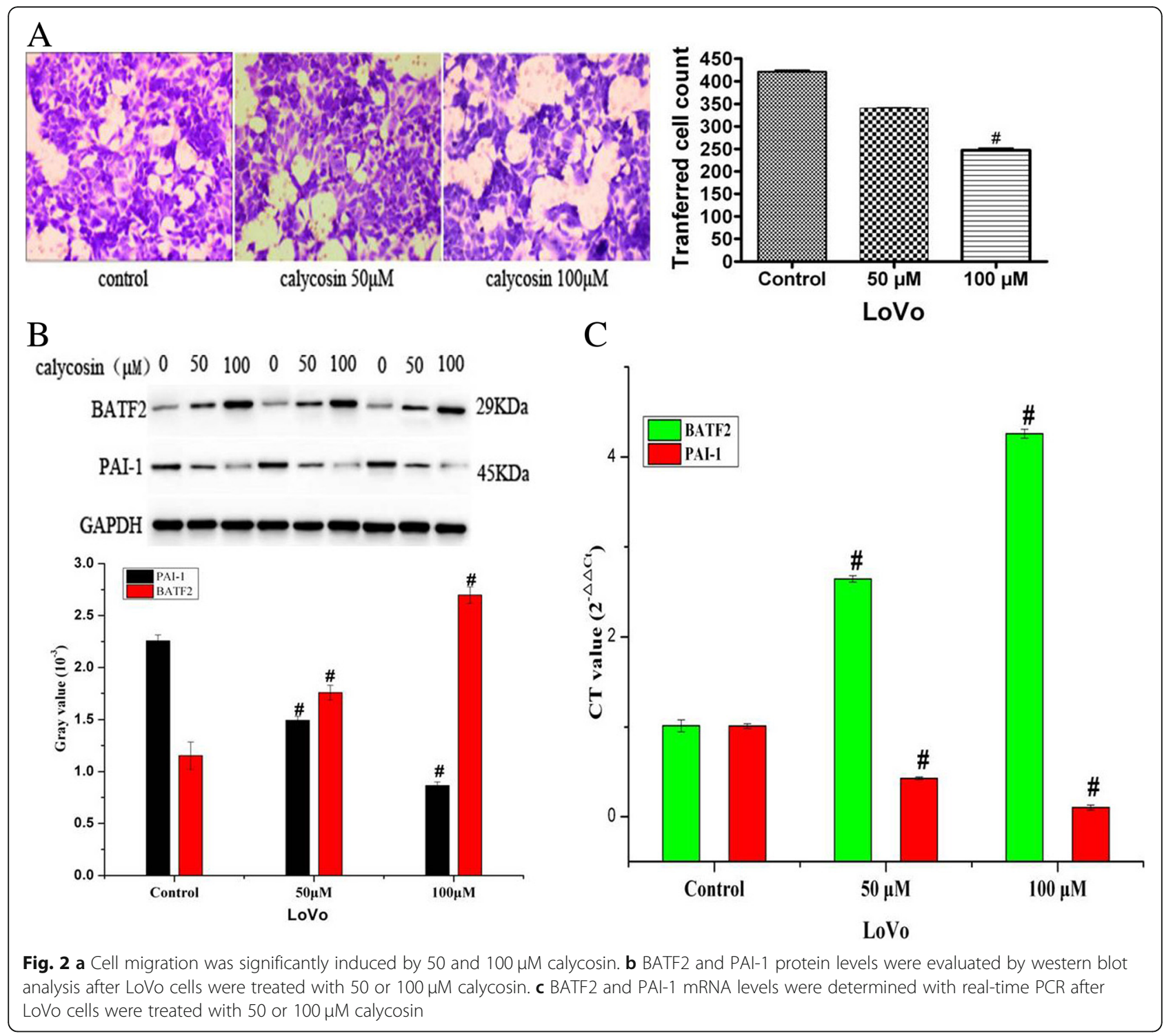

and TGF- $\beta$ were administered together, the upregulation of PCNA, p-Akt, and p-STAT3 by TGF- $\beta$ was inhibited $(P<0.05)$ (Fig. $3 \mathrm{a})$; the TGF- $\beta$-induced down-regulation of BAX expression was blocked by calycosin (Fig. 3a) and LY294002 (Fig. 3c); the TGF$\beta$-induced expression of PCNA was also blocked by calycosin (Fig. 3a) and LY294002 (Fig. 3c). Calycosin heightened the effect of LY294002. Compared to control cells, TGF- $\beta$ promoted cell proliferation $(P<0.05)$ (Fig. $3 \mathrm{~b})$, and calycosin suppressed cell growth in a time-dependent manner $(P<0.05)$ (Fig. 3b). The promotion of cell growth induced by TGF- $\beta$ was also effectively inhibited by calycosin (Fig. 3b), LY294002 (Fig. 3d), and calycosin with LY294002 (Fig. 3d) in a time-dependent manner $(P<0.05)$. The expression of BAX was increased by calycosin (Fig. 3c), LY294002 (PI3K signaling inhibitor), and calycosin with LY294002 (Fig. 3c). TGF- $\beta$ induced suppression of BAX expression was reversed by LY294002 (Fig. 3c). Cell proliferation was assessed by PCNA protein expression, which was increased by TGF- $\beta$, but decreased by calycosin $(P<$ 0.05) (Fig. 3d), LY294002, and calycosin with LY294002 (Fig. 3d).

\section{Calycosin enhanced the effect on TGF- $\beta$ induced apoptosis}

TGF- $\beta$ suppressed the expression of BAX that was recognized as maker of cell apoptosis and TGF- $\beta$ induced suppression of BAX expression was reversed by LY294002 and calycosin respectively. But the role of TGF- $\beta$ in cancer is complex and paradoxical,varying by cell type and stage of tumorigenesis. To identified the effect of TGF- $\beta$ on LoVo and HCT116 cells, apoptosis was determined by flow cytometry after LoVo and HCT116 cells were treated with PBS (Control), TGF- 


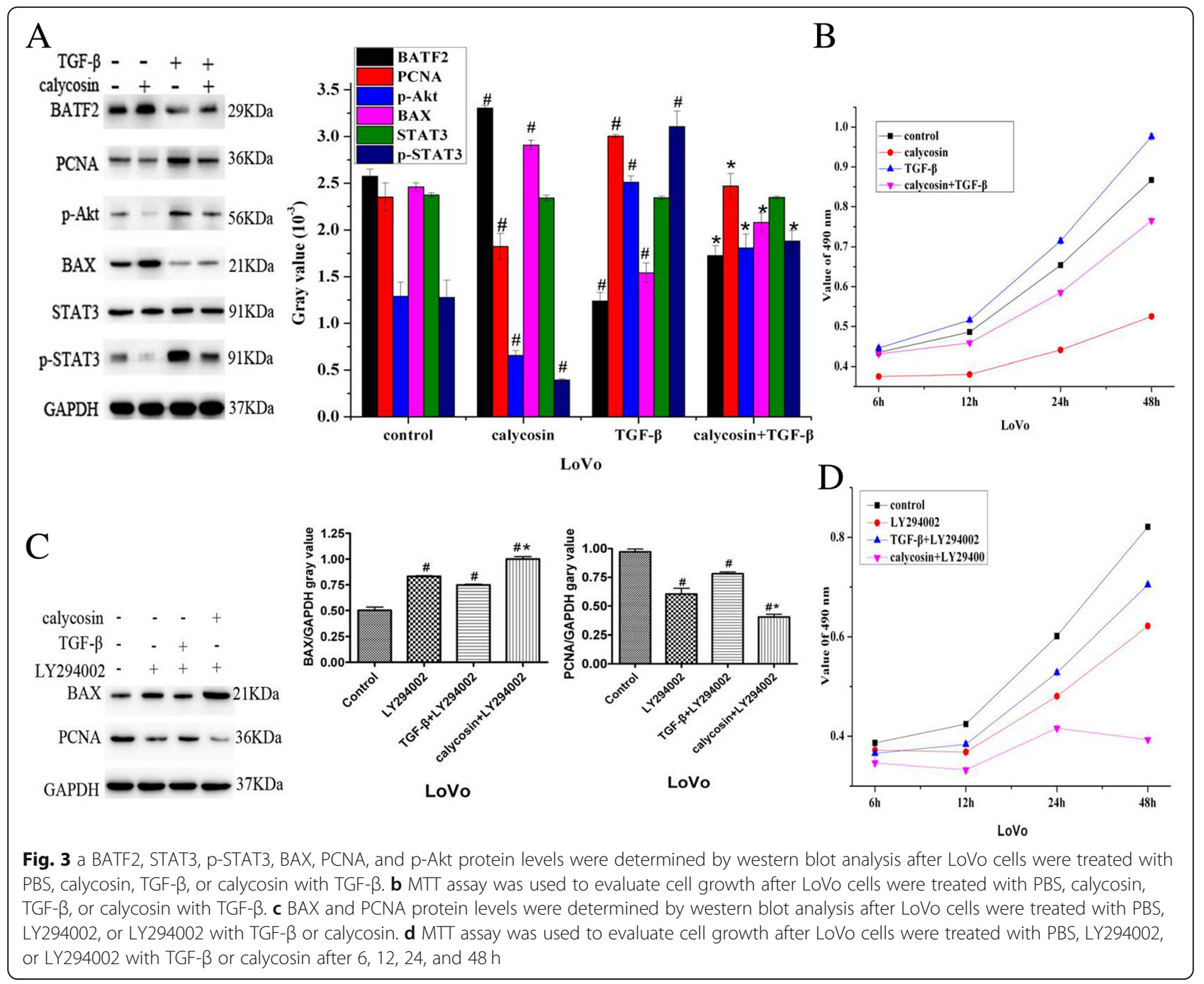

$\beta 20 \mathrm{ng} / \mathrm{ml}, \mathrm{calycosin} 100 \mu \mathrm{M}$ and TGF- $\beta$ combination with calycosin for $48 \mathrm{~h}$. As it was shown in Fig. 4, compared to the control, TGF- $\beta$ and calycosin promoted cell apoptosis respectively in both LoVo and HCT116 cell $(P<0.05)$. and cell apoptosis rates were upregulated to highest in combination group of TGF- $\beta$ and calycosin.

\section{Calycosin inhibits cell migration and regulates BATF2 and}

\section{PAI-1 expression in a dose-dependent manner}

To determine the relationship between the inhibition of cell migration and the expression of BATF2 and PAI-1, we evaluated the mRNA and protein levels of BATF2 and PAI-1, as their expression has been confirmed in distant metastases in human CRC. After culturing with 50 or $100 \mu \mathrm{M}$ calycosin for $48 \mathrm{~h}$, cell migration was inhibited in a dose-dependent manner. The number of migrated cells was decreased after treatment with $50 \mu \mathrm{M}$ calycosin for $48 \mathrm{~h}(P<0.05)$ (Fig. $2 \mathrm{a})$, and it was decreased further by treatment with $100 \mu \mathrm{M}$ calycosin for
$48 \mathrm{~h}(P<0.01)$ (Fig. 2a). As shown in Fig. $2 \mathrm{~b}$ and c, respectively, BATF2 protein and mRNA expression was increased by $50 \mu \mathrm{M} \quad(P<0.05)$ and $100 \mu \mathrm{M} \quad(P<0.01)$ calycosin. Conversely, PAI-1 protein and mRNA expression was decreased by $50 \mu \mathrm{M} \quad(P<0.05)$ and $100 \mu \mathrm{M}(P<0.01)$ calycosin. Thus, calycosin inhibited cell migration in a dose-dependent manner and regulated BATF2 and PAI-1 expression.

\section{Calycosin attenuates TGF- $\beta$-induced cell migration by regulating $\mathrm{PAI}-1$ mRNA and protein expression}

Cell migration was suppressed by the calycosinmediated downregulation of PAI-1, which is a target gene of TGF- $\beta$ that induces promoter activity and endogenous expression confirmed by us (Fig. 5a and b). Thus, we presumed that TGF- $\beta$-induced cell migration would be blocked by calycosin and the siRNA-mediated downregulation of PAI-1. Highly invasive human CRC LoVo and HCT116 cells were cultured for $48 \mathrm{~h}$ with PBS (control), $100 \mu \mathrm{M}$ calycosin, $20 \mathrm{ng} / \mathrm{mL}$ TGF- $\beta$, calycosin 


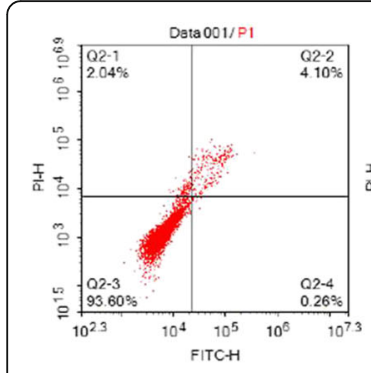

Control
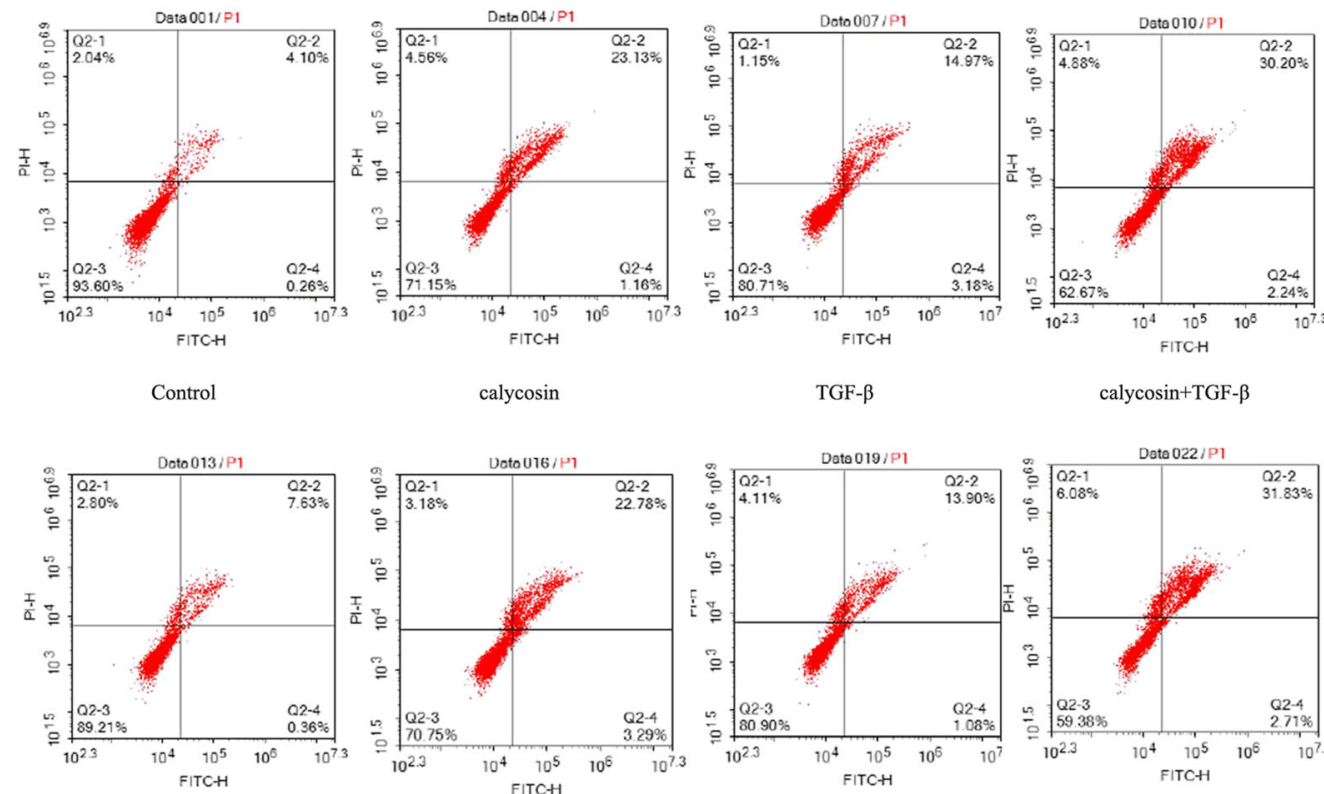

calycosin+TGF- $\beta$
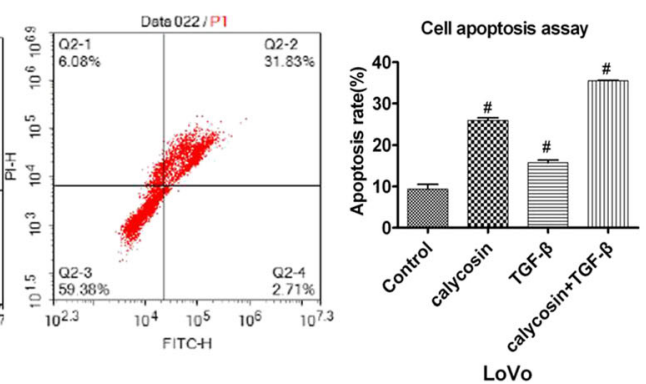

Fig. 4 After HCT116 and LoVo treated with PBS (control), $100 \mu \mathrm{M}$ calycosin, or $20 \mathrm{ng} / \mathrm{mL}$ TGF- $\beta$ and $100 \mu \mathrm{M}$ calycosin for $48 \mathrm{~h}$ cell apoptosis was determined by flow cytometry

with TGF- $\beta$, siPAI- 1 , TGF- $\beta$ with siPAI-1, or calycosin with siPAI-1. Cell migration was assessed with Transwell experiments. LoVo and HCT116 cell migration was promoted by TGF- $\beta(P<0.05)$ (Fig. $6 \mathrm{a}$ and $\mathrm{b})$ and suppressed by calycosin, siPAI- 1 , and calycosin with siPAI-1 $(P<0.05)$ (Fig. 6a and b). TGF- $\beta$-induced cell migration was decreased by calycosin, siPAI-1, and calycosin with siPAI-1 (Fig. 6a and b). In LoVo cells, PAI-1 protein and mRNA expression was up-regulated by TGF- $\beta(P<0.05)$ and down-regulated by calycosin (Fig. 6c, d; $P<0.05$ ). The upregulation of PAI- 1 by TGF- $\beta$ was completely suppressed by calycosin. The TGF- $\beta$-induced inhibition of cell migration caused by calycosin was in accordance with the TGF- $\beta$-induced inhibition of PAI-1 expression caused by calycosin.

\section{Direct targeting of PAI-1 by BATF2 is regulated by Calycosin and TGF- $\beta$ in an antagonistic manner}

To demonstrate the relationship between BATF2 and PAI-1 at the pre- and post-transcriptional levels, we performed luciferase assays to determine wild-type and mutant PAI-1 promoter activity induced by pEGFP-N1-BATF2 in LoVo cells after treatment with calycosin, TGF- $\beta$, or calycosin with TGF- $\beta$. The differentially treated CRC cells were collected and transfected with the plasmid constructs, and no significant fluorescence was observed in the blank control (pGL3-Basic) and mutant control plasmid (pGL3-PAI1-MT) groups. Compared to the pGL3-Basic and pGL3-PAI-1-MT plasmids, there was an increase of fluorescence from the pGL3-PAI-1-WT plasmid $(P<0.05)$ after the pEGFP-N1-BATF2 reporter construct was transfected into the cells. Luciferase assays in the control group indicated that the direct action of BATF2 on PAI-1 was at the pre-transcriptional level. Wild-type PAI-1 promoter activity was downregulated by calycosin $(P<0.05)$ and up-regulated by TGF- $\beta \quad(P<0.05)$. The promotion of TGF- $\beta$-induced PAI-1 promoter activity was partially blocked by caly$\operatorname{cosin}(P<0.05)$ (Fig. 5a). A co-immunoprecipitation assay confirmed the interaction of BATF2 and PAI-1 at the post-transcriptional level. Calycosin promoted the effect of BATF2 on PAI-1 (Fig. 5b), whereas TGF$\beta$ inhibited this effect. Calycosin attenuated the inhibitory effects of TGF- $\beta$ on the interaction between BATF2 and PAI-1.

\section{Calycosin blocks TGF- $\beta$-induced EMT via $\beta$-catenin nuclear translocation}

To investigate the role of calycosin in TGF- $\beta$-induced EMT and the underlying mechanisms, westernblotting was used to detect the expression of vimentin, Snail, and $\mathrm{N}$-cadherin, which function as negative regulators of EMT in CRC. The nucleus translocation of $\beta$-catenin was determined by using westernblotting to detect its expression in the cytoplasm and cytomembrane. Highly invasive human CRC LoVo and HCT116 cells were cultured with PBS (control), $100 \mu \mathrm{M}$ calycosin, $20 \mathrm{ng} / \mathrm{mL}$ TGF- $\beta$, or calycosin with TGF- $\beta$ for $48 \mathrm{~h}$ The expression of vimentin, Snail, N-cadherin was promoted by TGF- $\beta$ 


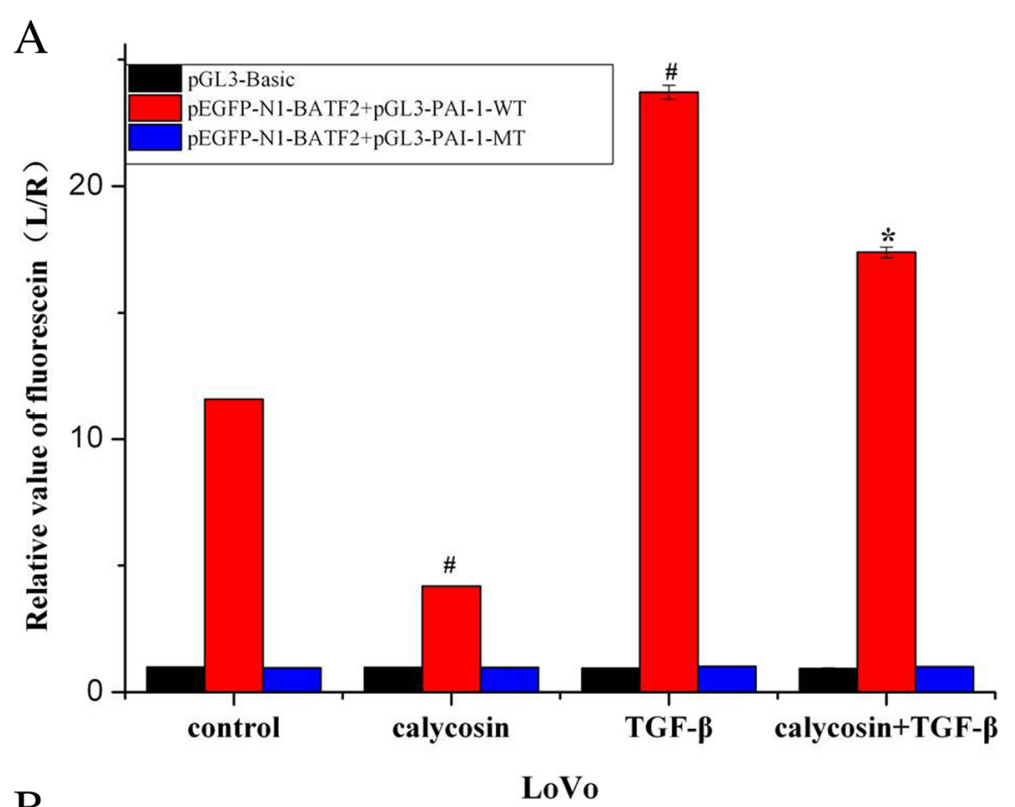

B

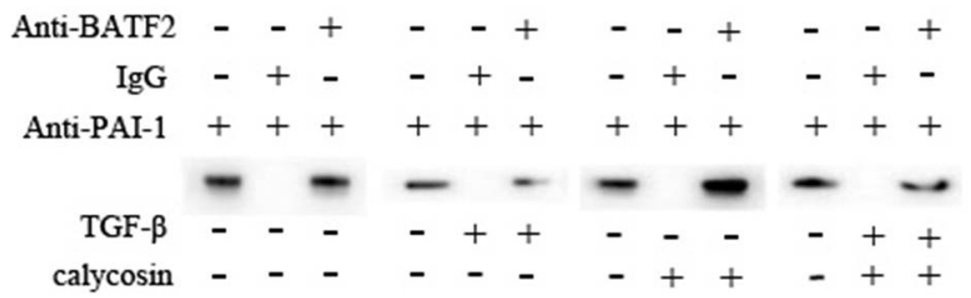

Fig. 5 a Wild-type and mutant PAI-1 promoter activity was determined by luciferase assays after transfection of LoVo cells with pEGFP-N1-BATF2 and treatment with calycosin, TGF- $\beta$, or calycosin with TGF- $\beta$. $\mathbf{b}$ After LoVo cells were treated with calycosin, TGF- $\beta$, or calycosin with TGF- $\beta$, a coimmunoprecipitation assay was performed with anti-BATF2 or lgG antibodies and anti-PAl-1 antibodies

$(P<0.05)$ and suppressed by calycosin $(P<0.05)$ in HCT116 (Fig. 7a) and LoVo cells (Fig. 7b). The TGF- $\beta$ induced upregulation of vimentin, Snail, and N-cadherin expression was blocked by calycosin in HCT116 cells (Fig. 7a) and attenuated by calycosin in LoVo cells (Fig. 7b) in the combined treatment group compared to the control group. Cytoblast $\beta$-catenin proteins were increased by TGF- $\beta$ and decreased by calycosin $(P<0.05)$ in HCT116 (Fig. 7a) and LoVo cells (Fig. 7b). Conversely, $\beta$-catenin expression in the cytomembrane was decreased by TGF- $\beta$ and increased by calycosin $(P<0.05)$ in HCT116 (Fig. 7a) and LoVo cells (Fig. $7 b)$. In spite of cell location in cytomembrane and nucleus, the changes in $\beta$-catenin protein induced by TGF- $\beta$ were blocked by calycosin $(P<0.05)$ (Fig. 7a, b).

Calycosin retains TGF- $\beta$-induced $\beta$-catenin nucleus import To determine whether calycosin and TGF- $\beta$ affect $\beta$ catenin localization in CRC cells, HCT116 and LoVo cells were heavily seeded, and $\beta$-catenin was analyzed by Cytoimmunofluorescence staining. Interestingly, $\beta$ catenin nuclear localization was clearly retained and induced by calycosin and TGF- $\beta$ conversely (Fig. 8).
Calycosin reversed TGF- $\beta$ - induced nucleus importing of $\beta$-catenin in both HCT116 and LoVo CRC cells (Fig. 8).

\section{Discussion}

Calycosin, is mainly bioactive compounds of isoflavones. It exhibit a variety of properties for alternative hormone therapy [19]. Calycosin was found able to play part alternative role of interferons and was considered as "plant interferon" in Chinese traditional medicine. Calycosin induces apoptosis and inhibits growth by reducing $\mathrm{p}$-Akt levels and down-regulating microRNA-95 in CRC cells [7]. BATF2 expression has been induced by interferons via STAT1 [20] and by AG490 via STAT3 [21]. STAT3 signaling can be antagonized by STAT1 [22], and accumulating evidence has shown that the PI3K and STAT3 pathways can be activated by TGF- $\beta[17,23,24]$. We wandered that whether BATF2 could be induced by calycosin as interferons did. In our study, TGF- $\beta$ simultaneously activated two signaling pathways: PI3K and STAT3, which were both inhibited by calycosin. BATF2 expression was down-regulated and up-regulated by 


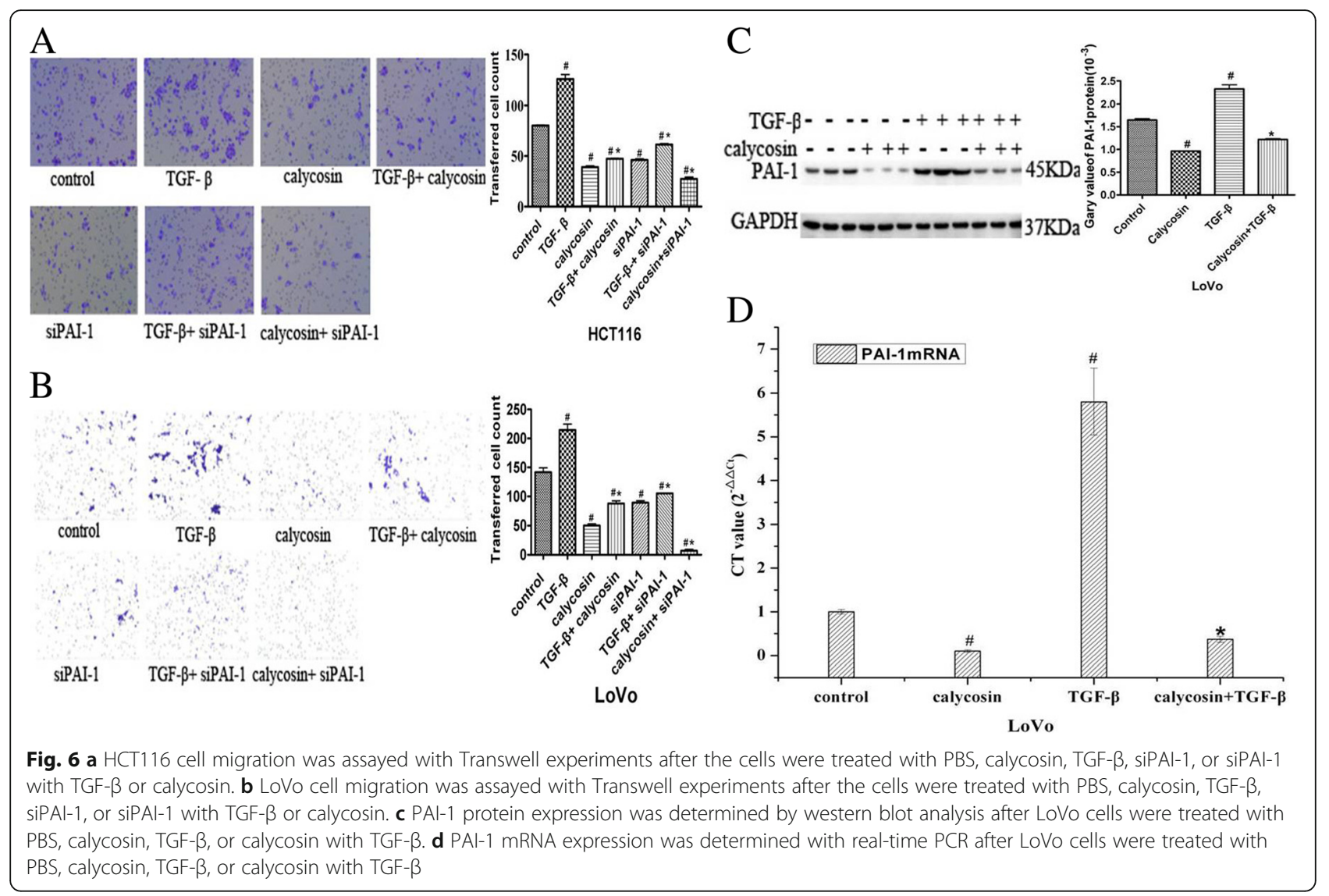

TGF- $\beta$ and calycosin, respectively, and TGF- $\beta$-reduced BATF2 expression could be rescued by calycosin. BATF2 is regulated by STAT3, which inhibits target gene promoter activity by promoting phosphorylation [18], and it has been demonstrated that the STAT signaling inhibitor AG490 up-regulates BATF2 mRNA expression, whereas the PI3K pathway inhibitor LY294002 has no such effect [22]. We successfully used calycosin to suppress TGF- $\beta$-induced-STAT3 phosphorylation. Thus, we believe that calycosin induces the upregulation of BATF2 expression antagonized by TGF- $\beta$ by inactivating the STAT3 signaling pathway. BATF2 overexpression promotes growth inhibition and apoptosis in cancer cells [25]. We revealed that the TGF$\beta$-induced regulation of PCNA and BAX expression and cell proliferation were repressed by an PI3K signaling inhibitor (LY294002) and calycosin, respectively, which exert their effects by inhibiting the phosphorylation of Akt. Furthermore calycosin heightened the effect of LY294002 on cell proliferation. We came to the conclusion that the TGF- $\beta$-induced promotion of growth blocked by calycosin involved the PI3K pathway via regulation of PCNA. We also uncovered that TGF- $\beta$ suppressed expression of BAX via PI3K /Akt sailing but cell apoptosis was promoted by
TGF- $\beta$, we presumed that it was maybe that apoptosis induced by TGF- $\beta$ was determined by the way more than PI3K /Akt, because it was reported that the ratio of Smad3 to Akt correlated with the sensitivity of cells to TGF- $\beta$ induced apoptosis [26, 27].

There is clinical evidence implicating PAI-1 as a key factor in tumor invasion and metastasis. PAI-1 is arguably one of the most well studied TGF- $\beta$-target genes, which is confirmed in the present study via luciferase reporter assays. However, the regulation of PAI- 1 gene expression by TGF- $\beta$ is not understood completely [28]. We discovered that when the PAI-1 gene was silenced with siRNA, cell migration and the TGF- $\beta$-induced migration of LoVo and HCT116 cells were significantly blocked. Calycosin inhibited cell migration by down-regulating PAI-1 and up-regulating BATF2 in a dose-dependent manner, and TGF- $\beta$ induced cell migration was also inhibited by calycosin in LoVo and HCT116 cells. Calycosin augmented the effect of siPAI-1 on the inhibition of cell migration. Both untreated and TGF- $\beta$-induced cell migration were suppressed by calycosin via the regulation of PAI-1 expression, which is associated with cell motility [29]. We demonstrated that the TGF- $\beta$-induced inhibition of cell migration caused by calycosin and siPAI-1 was in accordance with the TGF- $\beta$-induced 


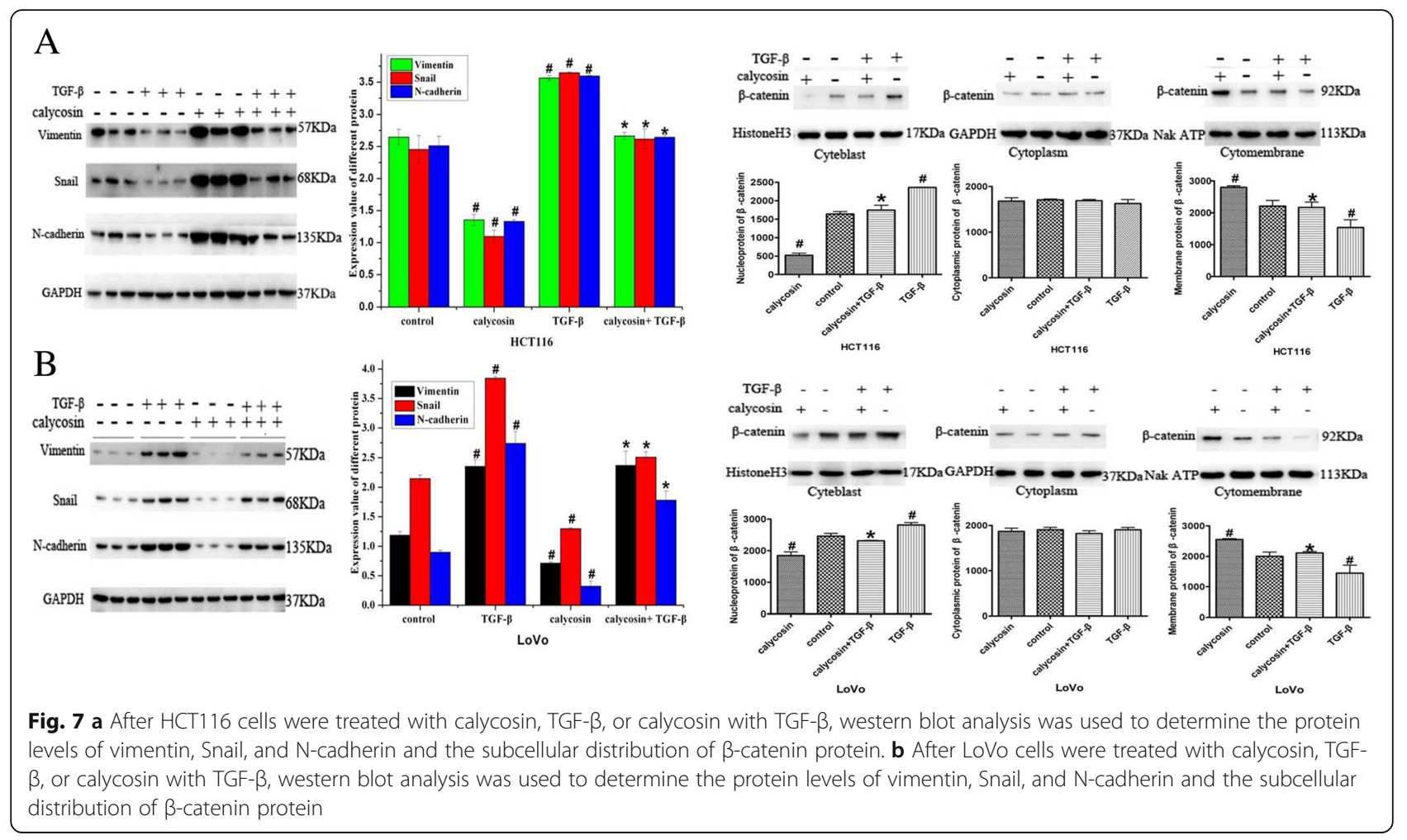

inhibition of PAI-1 expression caused by calycosin and siPAI-1.Further to elucidate the mechanisms underlying the calycosin-mediated regulation of TGF- $\beta$ signaling and PAI-1 and BATF2 expression, we performed luciferase reporter assays to confirm that TGF- $\beta$-induced PAI-1 promoter activity was inhibited by calycosin in accordance with the regulation of cell migration by calyco$\sin$. We also used co-immunoprecipitation assays to show that BATF2 regulated PAI-1, which was inhibited by TGF$\beta$. Calycosin attenuated the inhibitory effects of TGF- $\beta$ on the interaction of BATF2 with PAI-1. Thus, we conclude that TGF- $\beta$-induced cell migration can be suppressed by calycosin, which increases the expression of BATF2 to down-regulate PAI-1.

The progression of CRC to invasive and metastatic disease may involve the localized occurrence of EMT; the activation of EMT is considered a hallmark of metastasis in several human cancers. TGF- $\beta$ strongly induces EMT, which contributes to the generation and accumulation of fibroblasts and myofibroblasts responsible for the excessive deposition of extracellular matrix. TGF- $\beta$ signaling is a key EMT inducer in

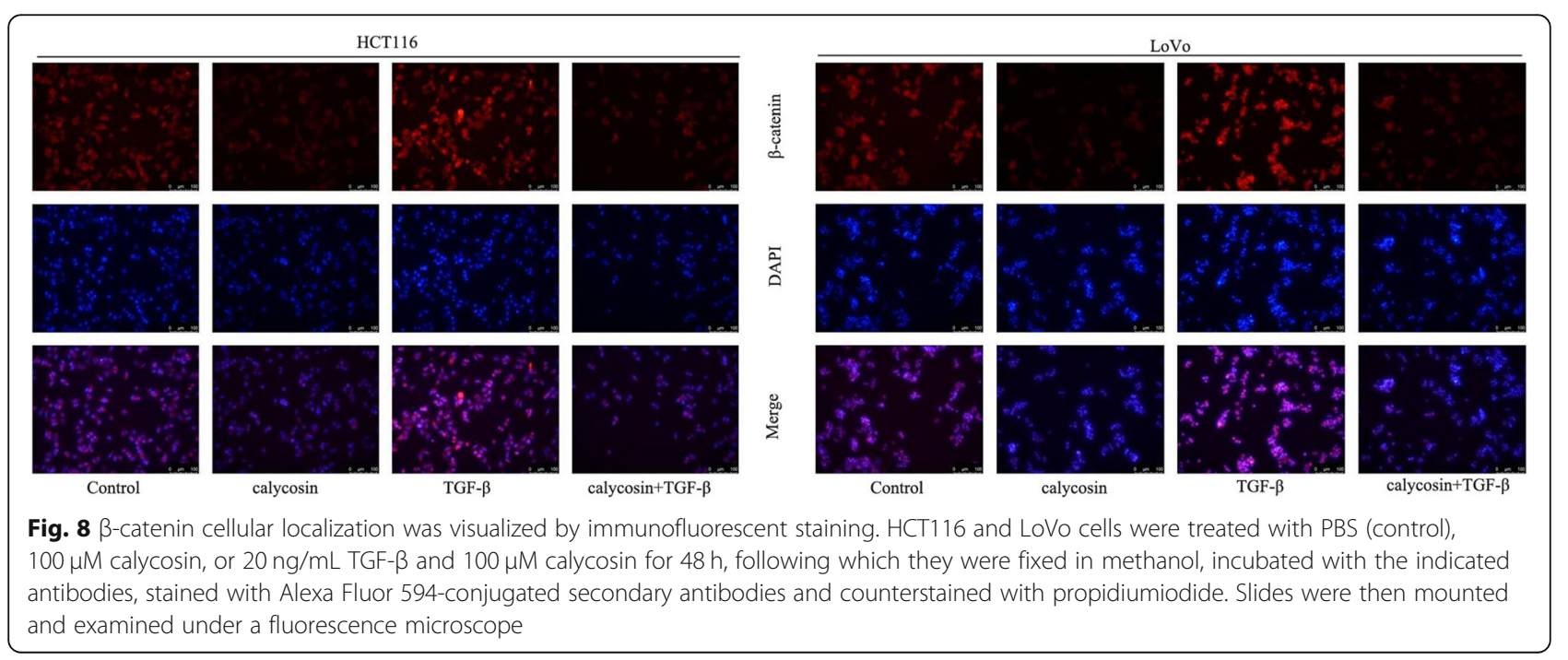


CRC [30], and we confirmed that TGF- $\beta$ induced EMT in CRC cells by promoting the expression of vimentin, Snail, and N-cadherin, which negatively regulated EMT in CRC cells. We found that TGF- $\beta$ induced EMT could be reversed by calycosin to suppress the expression of vimentin, Snail, and Ncadherin in LoVo and HCT116 cells. To determine whether BATF2 was involved in TGF- $\beta$-induced EMT, we analyzed the subcellular localization of $\beta$-catenin after LoVo and HCT116 cells were treated with TGF$\beta$, calycosin, or TGF- $\beta$ combination with calycosin. TGF- $\beta$ induced $\beta$-catenin localization from the cytomembrane to the cytoblast, and the TGF- $\beta$-induced nuclear accumulation of $\beta$-catenin was reversed by calycosin in HCT116 and LoVo cells. PI3K/Akt activation is believed to be essential for TGF- $\beta 1$-induced EMT in tumor cell lines [31]. Ormanns et al [32] reported that activation of the PI3K pathway was not associated with nucleus $\beta$-catenin expression in CRC cells. They concluded that although the transcriptional activity of nucleus $\beta$-catenin depended on PI3K activity. PI3K its own did not affect the subcellular localization of $\beta$-catenin. The inhibition of Akt phosphorylation caused by calycosin may be partially responsible for TGF- $\beta$-induced EMT via inactivation of the PI3K pathway. It was BATF2 induced by the calycosin in the cell nucleus mediated prevention of the TGF- $\beta$-induced nucleus accumulation of $\beta$-catenin, which is considered to be a sign of the activation of the Wnt signaling pathway. $\beta$-catenin degradation occurs in both the cytoplasm and nucleus according to Wnt status. In the "Wnt-off" state, $\beta$-catenin is mainly degraded in the cytoplasm, whereas in the "Wnt-on" state, it is mainly degraded in the nucleus via the ubiquitin proteasome system [33]. In the present study, no difference was found in $\beta$-catenin cytoplasmic expression in all groups, regardless of treatment, and the TGF- $\beta$-induced nuclear translocation of $\beta$-catenin was blocked by calycosin Thus, it is clear that the nucleus, and not cytoplasmic, degradation of $\beta$-catenin is activated by calycosin, which causes a switch to the "Wnt-on" state. In this state, $\beta$-catenin translocates into the nucleus due to the disassembly of the $\beta$-catenin destruction complex. $\beta$ catenin ubiquitination in the nucleus is mainly mediated by $\mathrm{c}-\mathrm{Cbl}$ and tripartite motif-containing protein 33 (TRIM33) [34, 35]. The possible relationship between calycosin with c-Cbl and TRIM33 should be evaluated in future studies.

PAI-1 is a canonical Wnt $/ \beta$-catenin signaling pathwayactivated gene in kidney tubular epithelial cells [27]; however, its role in CRC cells remains unknown, despite the direct regulation of PAI-1 by BATF2 identified in the present study. We also found that the $\mathrm{Wnt} / \beta$-catenin signaling was switched to the "Wnt-on" state by calycosin in CRC cells.

\section{Conclusion}

In summary, our study revealed that calycosin induced the upregulation of BATF2, which was antagonized by TGF- $\beta$ via the STAT3 signaling pathway to inhibit cell growth a through the PI3K pathway by Akt phosphorylation. TGF- $\beta$ suppressed expression of BAX via the phosphoinositide 3-kinase pathway but induced cell apoptosis .calycosin enhanced the effect of TGF- $\beta$ on cell apoptosis. It also demonstrated in our research that calycosin inhibited TGF- $\beta$-induced migration by upregulation of BATF2 to regulate PAI-1 expression directly and suppressed TGF- $\beta$-induced EMT by retaining $\beta$-catenin nuclear localization via the Wnt signaling pathway in human CRC LoVo and HCT116 cells. Thus, we conclude that the upregulation of BATF2 induced by calycosin may be a therapeutic option for CRC.

\section{Abbreviations \\ Akt: Protein kinase B; AP-1: Active protein-1; BATF: Basic leucine zipper ATF- like transcription factor 2; BAX: BCL2-associated X; CRC: Colorectal carcinoma; EMT: Epithelial-to-mesenchymal transition; PAI-1: Plasminogen activator inhibitor-1; p-Akt: Phosphorylated protein kinase B; PBS: Phosphate-buffered saline; PCNA: Proliferating cell nuclear antigen; PI3K: Phosphoinositide 3- kinase; $\mathrm{p}$-STAT3-phosphorylated: Signal transducer and activator of transcription 3; siRNA: Small interfering RNA; STAT3: Signal transducer and activator of transcription 3; TGF- $\beta$ : Transforming growth factor beta}

\section{Acknowledgements}

We gratefully acknowledge the Professor Liu Jun, Tumor Center of Union Medical College Affiliated to Tongji Medical College, Hua zhong University of Science and Technology, for providing technical support.

\section{Authors' contributions}

QW, TY, and LL conceived and designed the study. QW carried out the experiments. QW, WJL, and LL analyzed the data. QW and LL drafted and revised the manuscript. All authors read and approved the final manuscript.

Funding

Our project was supported by Joint Fund Project of Hubei Provincial Health Commission: WJ2019H129, China.

Availability of data and materials

Please contact author for data requests.

Ethics approval and consent to participate

Not applicable.

Consent for publication

All of the authors consent for publication in the Journal of Experiment and Clinical Cancer.

\section{Competing interests}

The authors declare that they have no competing interests.

\section{Author details}

${ }^{1}$ Department of Hepatopancreatobiliary Surgery, Hubei Cancer Hospital, Wuhan, Hubei 430079, People's Republic of China. ${ }^{2}$ Department of Medical Oncology, Hubei Cancer Hospital, Tongji Medical College, Huazhong University of Science and Technology, Wuhan, Hubei 430079, People's Republic of China. ${ }^{3}$ Colorectal Cancer Clinical Research Center of Wuhan, Wuhan, Hubei 430079, People's Republic of China. ${ }^{4}$ Colorectal Cancer Clinical Research Center of Hubei Province, Wuhan, Hubei 430079, People's Republic 
of China. ${ }^{5}$ Department of Gastrointestinal Surgery, Hubei Cancer Hospital, Wuhan, Hubei 430079, People's Republic of China.

Received: 29 January 2019 Accepted: 23 May 2019

Published online: 07 June 2019

\section{References}

1. Murphy TL, Tussiwand R, Murphy KM. Specificity through cooperation: BATF-IRF interactions control immune-regulatory networks. Nat Rev Immunol. 2013;13:499-509.

2. Echlin DR, Tae HJ, Mitin N, Taparowsky EJ. B-ATF functions as a negative regulator of AP-1 mediated transcription and blocks cellular transformation by Ras and Fos. Oncogene. 2000;19:1752-63.

3. Williams KL, Nanda I, Lyons GE, Kuo CT, Schmid M, Leiden JM, Kaplan MH, Taparowsky EJ. Characterization of murine BATF: a negative regulator of activator protein-1 activity in the thymus. Eur J Immunol. 2001;31:1620-7.

4. Liu Z, Wei P, Yang Y, Cui W, Cao B, Tan C, Yu B, Bi R, Xia K, Chen W, Wang Y, Zhang Y, Du X, Zhou X. BATF2 deficiency promotes progression in human colorectal cancer via activation of HGF/MET signaling: a potential rationale for combining MET inhibitors with IFNs. Clin Cancer Res. 2015;21:1752-63.

5. Dai L, Cui X, Zhang X, Cheng L, Liu Y, Yang Y, Fan P, Wang Q, Lin Y, Zhang J, Li C, Mao Y, Wang Q, Su X, Zhang S, Peng Y, Yang H, Hu X, Yang J, Huang M, Xiang R, Yu D, Zhou Z, Wei Y, Deng H. SARI inhibits angiogenesis and tumour growth of human colon cancer through directly targeting ceruloplasmin. Nat Commun. 2016;7:11996.

6. Ma H, Liang X, Chen Y, Pan K, Sun J, Wang H, Wang Q, Li Y, Zhao J, Li J, Chen $\mathrm{M}$, Xia J. Decreased expression of BATF2 is associated with a poor prognosis in hepatocellular carcinoma. Int J Cancer. 2011;128:771-7.

7. Wen H, Chen Y, Hu Z, Mo Q, Tang J, Sun C. Decreased expression of BATF2 is significantly associated with poor prognosis in oral tongue squamous. Oncol Rep. 2014;31:169-74.

8. Bhowmick NA, Ghiassi M, Bakin A, Aakre M, Lundquist CA, Engel ME, Arteaga $\mathrm{CL}$, Moses $\mathrm{HL}$. Transforming growth factor- $\beta 1$ mediates epithelial to mesenchymal transdifferentiation through a RhoA-dependent mechanism. Mol Biol Cell. 2001;12:27-36.

9. Ellenrieder V, Hendler SF, Boeck W, Seufferlein T, Menke A, Ruhland C, Adler G, Gress TM. Transforming growth factor $\beta 1$ treatment leads to an epithelial-mesenchymal transdifferentiation of pancreatic cancer cells requiring extracellular signal-regulated kinase 2 activation. Cancer Res. 2001; 1:4222-8.

10. Lampropoulos P, Zizi-Sermpetzoglou A, Rizos S, Kostakis A, Nikiteas N, Papavassiliou AG. TGF-beta signalling in colon carcinogenesis. Cancer Lett. 2012;314:1-7.

11. Schroy P, Rifkin J, Coffey RJ, Winawer S, Friedman E. Role of transforming growth factor $\beta 1$ in induction of colon carcinoma differentiation by hexamethylene bisacetamide. Cancer Res. 1990;50:261-5.

12. Tsushima H, Ito N, Tamura S, Matsuda Y, Inada M, Yabuuchi I, Imai Y, Nagashima R, Misawa H, Takeda H, Matsuzawa Y, Kawata S. Circulating transforming growth factor $\beta 1$ as a predictor of liver metastasis after resection in colorectal cancer. Clin Cancer Res. 2001;7:1258-62.

13. Joyce T, Cantarella D, Isella C, Medico E, Pintzas A. A molecular signature for epithelial to mesenchymal transition in a human colon cancer cell system is revealed by large-scale microarray analysis. Clin Exp Metastasis. 2009;26:569-87.

14. Gulhati P, Bowen KA, Liu J, Stevens PD, Rychahou PG, Chen M, Lee EY, Weiss $\mathrm{HL}$, O'Connor KL, Gao T, Evers BM. MTORC1 and mTORC2 regulate EMT, motility, and metastasis of colorectal cancer via RhoA and Rac1 signaling pathways. Cancer Res. 2011;71:3246-56.

15. Cottonham CL, Kaneko S, Xu L. miR-21 and miR-31 converge on TIAM1 to regulate migration and invasion of colon carcinoma cells. J Biol Chem. 2010; 285:35293-302.

16. Kalogeropoulou M, Voulgari A, Kostourou V, Sandaltzopoulos R, Dikstein R, Davidson I, Tora L, Pintzas A. TAF4b and Jun/activating protein-1 collaborate to regulate the expression of integrin 6 and cancer cell migration properties. Mol Cancer Res. 2010;8:554-68

17. Wang G, Yu Y, Sun C, Liu T, Liang T, Zhan L, Lin X, Feng XH. STAT3 selectively interacts with Smad3 to antagonize TGF- $\beta$. Oncogene. 2016;35:4388-98.

18. Liao J, Humphrey SE, Poston S, Taparowsky EJ. Batf promotes growth arrest and terminal differentiation of mouse myeloid leukemia cells. Mol Cancer Res. 2011;9:350-63.
19. Tian J, Wang Y, Zhang X, Ren Q, Li R, Huang Y, Lu H, Chen J. Calycosin inhibits the in vitro and in vivo growth of breast cancer cells through WDR7-7-GPR30 signaling. J Exp Clin Cancer Res. 2017;2(36):153.

20. Guler R, Roy S, Suzuki H, Brombacher F. Targeting Batf2 for infectious diseases and cancer. Oncotarget. 2015;6:26575-82.

21. Huang $Q$, Yang $Y, L i X$, Huang S. Transcription suppression of SARI (suppressor of AP-1, regulated by IFN) by BCR-ABL in human leukemia cells. Tumour Biol. 2011;32:1191-7.

22. Cheon $\mathrm{H}$, Yang J, Stark GR. The functions of signal transducers and activators of transcriptions 1 and 3 as cytokine-inducible proteins. J Interf Cytokine Res. 2011;31:33-40.

23. Chow JYC, Cabral JA, Chang J, Carethers JM. TGF $\beta$ modulates PTEN expression independently of SMAD signaling for growth proliferation in colon cancer cells. Cancer Biol Ther. 2008;7:1694-9.

24. Jenkins BJ, Grail D, Nheu T, Najdovska M, Wang B, Waring P, Inglese M, McLoughlin RM, Jones SA, Topley N, Baumann H, Judd LM, Giraud AS, Boussioutas A, Zhu HJ, Ernst M. Hyperactivation of Stat3 in gp130 mutant mice promotes gastric hyperproliferation and desensitizes TGF- $\beta$ signaling. Nat Med. 2005;11:845-52.

25. Su ZZ, Lee SG, Emdad L, Lebdeva IV, Gupta P, Valerie K, Sarkar D, Fisher PB. Cloning and characterization of SARI (suppressor of AP-1, regulated by IFN). Proc Natl Acad Sci U S A. 2008;105:20906-11.

26. Conery AR, Cao Y, Thompson EA, Townsend CM Jr, Ko TC, Luo K. Akt interacts directly with Smad3 to regulate the sensitivity to TGF-beta induced apoptosis. Nat Cell Biol. 2004;6:366-72.

27. Remy I, Montmarquette A, Michnick SW. PKB/Akt modulates TGF-beta signalling through a direct interaction with Smad3. Nat Cell Biol. 2004;6: 358-65.

28. He W, Tan R, Dai C, Li Y, Wang D, Hao S, Kahn M, Liu Y. Plasminogen activator inhibitor-1 is a transcriptional target of the canonical pathway of Wnt/B-catenin signaling. J Biol Chem. 2010;285:24665-75.

29. Czekay RP, Wilkins-Port CE, Higgins SP, Freytag J, Overstreet JM, Klein RM, Higgins CE, Samarakoon R, Higgins PJ. PAl-1: an integrator of cell signaling and migration. Int J Cell Biol. 2011;2011:562481.

30. Xiong H, Hong J, Du W, Lin YW, Ren LL, Wang YC, Su WY, Wang JL, Cui Y, Wang ZH, Fang JY. Roles of STAT3 and ZEB1 proteins in E-cadherin downregulation and human colorectal cancer epithelial-mesenchymal transition. J Biol Chem. 2012;287:5819-32.

31. Bakin AV, Tomlinson AK, Bhowmick NA, Moses HL, Arteaga CL. Phosphatidylinositol 3-kinase function is required for transforming growth factor $\beta$-mediated epithelial to mesenchymal transition and cell migration. J Biol Chem. 2000;275:36803-10.

32. Ormanns S, Neumann J, Horst D, Kirchner T, Jung A. WNT signaling and distant metastasis in colon cancer through transcriptional activity of nuclear $\beta$-catenin depend on active PI3K signaling. Oncotarget. 2014;5:2999-3011.

33. Shang $\mathrm{S}$, Hua F, Hu ZW. The regulation of $\beta$-catenin activity and function in cancer: therapeutic opportunities. Oncotarget. 2017;8:33972-89.

34. Chitalia V, Shivanna S, Martorell J, Meyer R, Edelman E, Rahimi N. C-Cbl, a ubiquitin E3 ligase that targets active $\beta$-catenin: a novel layer of Wnt regulation. J Biol Chem. 2013;288:23505-17.

35. Xue J, Chen Y, Wu Y, Wang Z, Zhou A, Zhang S, Lin K, Aldape K, Majumder S, Lu Z, Huang S. Tumour suppressor TRIM33 targets nuclear $\beta$-catenin degradation. Nat Commun. 2015;6:6156.

\section{Publisher's Note}

Springer Nature remains neutral with regard to jurisdictional claims in published maps and institutional affiliations.

\section{Ready to submit your research? Choose BMC and benefit from:}

- fast, convenient online submission

- thorough peer review by experienced researchers in your field

- rapid publication on acceptance

- support for research data, including large and complex data types

- gold Open Access which fosters wider collaboration and increased citations

- maximum visibility for your research: over $100 \mathrm{M}$ website views per year

At BMC, research is always in progress.

Learn more biomedcentral.com/submissions 